\title{
Sustenance of Soil Fertility under Organic and Inorganic Mulching in Acid Lime (Citrus aurantifolia Swingle)
}

\author{
Esther Lalruatsangi $^{1 *}$, A.S. Mailappa ${ }^{2}$ and B.N. Hazarika ${ }^{3}$ \\ ${ }^{1}$ Department of Fruit Science, College of Horticulture, Central Agricultural University, \\ Thenzawl, Mizoram, India \\ ${ }^{2}$ Department of Natural Resource Management, College of Horticulture and Forestry, \\ Central Agricultural University, Pasighat, Arunachal Pradesh, India \\ ${ }^{3}$ Department of Fruit Science, College of Horticulture and Forestry, Central Agricultural \\ University, Pasighat, Arunachal Pradesh, India \\ *Corresponding author
}

\section{A B S T R A C T}

An investigation was carried out to study the effects of organic and inorganic mulching on soil properties in acid lime at Fruit Research Farm,

\section{Keywords}

Acid lime, Organic mulch, Inorganic mulch, Soil properties

\section{Article Info}

Accepted:

20 June 2020

Available Online:

10 July 2020
College of Horticulture and Forestry, Central Agricultural University, Pasighat, Arunachal Pradesh. The experiment was laid out in Randomized Block Design with 9 treatments and 3 replications. The maximum moisture content $(36.06 \%)$ was observed in polythene mulch with black side facing upward $\left(\mathrm{T}_{8}\right)$ while maximum organic carbon $(3.11 \%)$, available nitrogen (428.47 kg/ha), phosphorus (45.17 kg/ha) and potassium $(575.06 \mathrm{~kg} / \mathrm{ha})$ content was recorded by saw dust mulch $\left(\mathrm{T}_{7}\right)$. The treatment recorded highest microbial population of bacteria $\left(83.45 \times 10^{5}\right)$ in paddy straw mulch $\left(\mathrm{T}_{4}\right)$ and fungi $\left(119.34 \times 10^{5}\right)$ in rice husk mulch $\left(\mathrm{T}_{5}\right)$. The study revealed that organic mulches have beneficial effect on soil properties as compared to inorganic mulches. Among the treatments, saw dust and paddy straw mullch proves to be the best ideal treatment for improving soil properties in acid lime.

\section{Introduction}

Acid lime (Citrus aurantifolia Swingle) is the third important citrus fruit crop in India next to mandarin and sweet orange (Chadha, 2002). The fruit is valued not only for its nutritional qualities but also for pharmaceutical, nutraceutical, cosmeceutical, 
medicinal and health value. The quality production of Citrus fruits is highly dependent on the soil moisture availability. In North Eastern Region, rainfall increase gradually from the month of March which continues up to last week of October wherein maximum rainfall is observed during the month of June to September from South-West monsoon. However, the months of November to March are deprived of rainfall thus producing a dry period. Proper management of available irrigation water and conservation of moisture for longer duration in the root zone of the tree canopy plays an important role in enhancing the yield and quality of fruits in acid lime. Mulching plays an important role in conservation of soil moisture during dry periods, as well as improves physical, biological and chemical properties of soil. It is a practice, which helps in proper growth and development of the plants by modifying soil temperature, providing better nutrient availability and by better moisture conservation (Kher et al., 2010). Organic mulches and inorganic mulch are efficient in reduction of nitrates leaching, improve soil physical properties, prevent erosion, supply organic matter, regulate temperature and water retention, improve nitrogen balance, take part in nutrient cycle as well as increase the biological activity (Muhammad et al., 2009; Sarolia and Bhardwaj, 2012). Organic mulches are derived from plant and animal while inorganic mulches such as plastic mulch are permanent and do not decompose over time. The effective use of polyethylene and organic mulches was evaluated for improving the growth, yield and quality of the Coorg mandarin (Mustaffa, 1989), Assam lemon (Nath and Sharma, 1993), Nagpur mandarin (Shirgure et al., 2003) and acid lime (Shirgure, 2012). The information on mulching materials and its effect on soil health in acid lime suitable for North Eastern conditions was not known. Therefore, an investigation was done to find out the effect of organic and inorganic mulching materials on soil properties in acid lime.

\section{Materials and Methods}

The experiment was carried out on 6 years old of acid lime var. PKM 1 planted at spacing of $3 \mathrm{~m} \times 3 \mathrm{~m}$, these plants were treated with different mulches at Fruit Research Farm, College of Horticulture and Forestry, Central Agricultural University, Pasighat, Arunachal Pradesh. The experiment consisted of nine treatments in a Randomized Block design with three replications. The treatments were $\mathrm{T}_{1}=$ No mulch $($ Control $), \mathrm{T}_{2}=$ Dry grasses, $\mathrm{T}_{3}$ $=$ Banana leaves, $\mathrm{T}_{4}=$ Paddy straw, $\mathrm{T}_{5}=$ Rice husk, $\mathrm{T}_{6}=$ Wood shavings, $\mathrm{T}_{7}=$ Saw dust, $\mathrm{T}_{8}$ $=$ Polythene mulch with black side facing upward and $\mathrm{T}_{9}=$ Polythene mulch with silver side facing upward. The dry grasses mulch and banana leaves mulch materials were imposed on $3 \mathrm{~kg} / \mathrm{basin}$ around the tree trunk, while the remaining organic mulch materials viz. paddy straw, rice husk, wood shavings and saw dust was applied as $6 \mathrm{~cm} /$ thickness around the canopy during the study period. The surface $(0-15 \mathrm{~cm})$ soil samples were used for analyzing the soil properties. The soil properties were determined using soil analytical methods given by Jackson (1973). Organic carbon content determined by wet digestion method of Walkley and Black, available nitrogen $(\mathrm{N})$ by Kjeldahl's method, available phosphorous (P) by Bray and Kurtz method and available potassium $(\mathrm{K})$ by flame photometric method. The data collected on various parameters have been statistically analysed as per the method of Panse and Sukhatme (1978).

\section{Results and Discussion}

The effect of various mulching materials on soil moisture content, organic carbon, available nitrogen, phosphorus, potassium content and microbial population has been 
observed showing a great significance although there was no significant observation regarding the soil $\mathrm{pH}$. The maximum soil moisture content $(36.06 \%)$ was observed in polythene mulch with black side facing upward $\left(\mathrm{T}_{8}\right)$ while organic carbon $(3.11 \%)$, available nitrogen $(428.47 \mathrm{~kg} / \mathrm{ha})$, available phosphorus (45.17 $\mathrm{kg} / \mathrm{ha})$ and potassium $(575.06 \mathrm{~kg} / \mathrm{ha})$ in saw dust mulch $\left(\mathrm{T}_{7}\right)($ Table 1). The different mulching materials had shown variations in different soil properties.
The available nitrogen status in post harvest soils increased successively with increasing nitrogen levels which was due to integration of organic and inorganic sources and also due to increased microbial activity which could have stimulated the nitrification process. Among the organic mulches, saw dust mulch $\left(\mathrm{T}_{7}\right)$ proves to have a profound beneficial effect on the soil properties although the other treatments were in par with $\mathrm{T}_{7}$.

Table.1 Effect of organic and inorgnic mulching on soil parameters

\begin{tabular}{|c|c|c|c|c|c|c|}
\hline Treatments & Soil pH & $\begin{array}{c}\text { Soil } \\
\text { moisture } \\
\text { content }(\%)\end{array}$ & $\begin{array}{c}\text { Organic } \\
\text { carbon } \\
(\%)\end{array}$ & $\begin{array}{c}\text { Available } \\
\text { nitrogen } \\
\text { (kg/ha) }\end{array}$ & $\begin{array}{c}\text { Available } \\
\text { phosphorus } \\
\text { (kg/ha) }\end{array}$ & $\begin{array}{c}\text { Available } \\
\text { potassium } \\
\text { (kg/ha) }\end{array}$ \\
\hline $\mathbf{T}_{1}$ & 5.45 & 24.20 & 2.19 & 296.83 & 24.27 & 440.83 \\
\hline $\mathbf{T}_{2}$ & 5.37 & 33.66 & 2.85 & 388.80 & 44.80 & 511.46 \\
\hline $\mathbf{T}_{\mathbf{3}}$ & 5.41 & 29.11 & 2.49 & 347.10 & 31.73 & 482.16 \\
\hline $\mathbf{T}_{4}$ & 5.53 & 30.26 & 3.03 & 367.63 & 41.81 & 556.92 \\
\hline $\mathbf{T}_{5}$ & 5.32 & 28.66 & 2.94 & 376.27 & 42.93 & 559.35 \\
\hline $\mathbf{T}_{6}$ & 5.97 & 26.73 & 2.76 & 409.73 & 38.08 & 527.86 \\
\hline $\mathbf{T}_{7}$ & 5.90 & 29.66 & 3.11 & 428.47 & 45.17 & 575.06 \\
\hline $\mathbf{T}_{8}$ & 5.33 & 36.06 & 2.60 & 355.77 & 36.21 & 520.43 \\
\hline $\mathbf{T}_{9}$ & 5.32 & 35.25 & 2.56 & 334.70 & 34.34 & 514.13 \\
\hline S.Ed \pm & - & 2.99 & 0.21 & 33.98 & 5.96 & 32.17 \\
\hline $\begin{array}{c}\text { C.D } \\
\text { at } 5 \%\end{array}$ & N.S & 6.34 & 0.44 & 72.03 & 12.65 & 68.21 \\
\hline
\end{tabular}

The experimental study concluded that both organic and inorganic mulching materials had significantly influenced moisture conservation and nutrient content in acid lime as compared to control (no mulch). The moisture regulation is of utmost importance and needs to be emphasized as a priority at critical stages of growth. Moisture conservation was found to be higher in inorganic mulch due to use of synthetic plastic materials. Higher nutrient inputs in the soil occurred under organic mulch conditions. The organic mulches such as paddy straw $\left(\mathrm{T}_{4}\right)$, rice husk $\left(\mathrm{T}_{5}\right)$ and saw dust mulches $\left(\mathrm{T}_{7}\right)$ reveals to give the best results for improving soil properties of acid lime. The inorganic mulch gives good result but organic mulches such as rice husk, paddy straw and saw dust mulches are more recommended as compared to the inorganic mulch since they are readily available raw material resulting higher cost benefit ratio.

\section{References}

Chadha, K.L. Limes and Lemons. In: Handbook of Horticulture. Published by Directorate of Information and Publication of Agriculture, ICAR, Krishi Anusandhan Bhavan, Pusa, New Delhi. 2002. pp. 209. 
Jackson, M.L. Soil chemical analysis. Prentice Hall of India Private Limited, New Delhi. 1973.

Kher, R., Baba, J.A., Bakshi, P. Influence of planting time and mulching material on growth and fruit yield of strawberry cv. Chandler. Indian Journal of Horticulture. $67^{\text {th }}$ ed. Vol. 4. 2010. pp 441-444.

Muhammad, A.P., Muhammad, I., Khuram, S., Anwar-UL-Hassan. 2009. Effect of mulch on soil physical properties and NPK concentration in maize (Zea mays) shoots under two tillage system. International Journal of Agriculture and Biology. $11^{\text {th }}$ ed. 2009. pp 120-124.

Mustaffa M M. 1989. Effect of mulching and shade on yield, quality and leaf nutrient composition of Coorg mandarin. Indian Journal of Horticulture, $46^{\text {th }}$ ed. Vol. 3. 1989. pp. 344-347.

Nath J C., Sharma R. 1993. Leaf chlorophyll and leaf relative water of Assam lemon (Citrus limon B.) as affected by organic mulches. South Indian Horticulture, $41^{\text {th }}$ ed. Vol. 4. 1993. pp. 225-226.

Panse, V.G., Sukhatme, D.K. Statistical Methods for Agricultural Workers $\left(3^{\text {rd }}\right.$ ed.), ICAR, New Delhi. 1974

Sarolia, D.K., Bhardwaj, R.L. Effect of mulching on crop production under rainfed condition- A Review. International Journal of Research in Chemistry and Environment. $2^{\text {nd }}$ ed. 2012. pp. 8-20.

Shirgure, P.S. 2012. Sustainable acid lime fruit production and soil moisture conservation with different mulches. Agricultural Engineering Today. $36^{\text {th }}$ ed. Vol. 3. 2012. pp. 21-26

Shirgure, P.S., Sonkar, R.K., Singh, S., Panigrah, P. 2003. Effect of different mulches on soil moisture conservation, weed reduction, growth and yield of drip irrigated Nagpur mandarin (Citrus reticulata). Indian Journal of Agricultural Sciences. $73^{\text {rd }}$ ed. Vol. 3 . 2003. pp. 148-152.

\section{How to cite this article:}

Esther Lalruatsangi, A.S. Mailappa and Hazarika, B.N. 2020. Sustenance of Soil Fertility under Organic and Inorganic Mulching in Acid Lime (Citrus aurantifolia Swingle). Int.J.Curr.Microbiol.App.Sci. 9(07): 2320-2323. doi: https://doi.org/10.20546/ijcmas.2020.907.271 